JURNAL BALI MEMBANGUN BALI

Volume 1 Nomor 3, Desember 2020

e-ISSN 2722-2462 p-ISSN 2722-2454

http://ejournal.baliprov.go.id/

\title{
Bali in the Covid-19 Pandemic: Population and Employment Dilemmas
}

\author{
I Gusti Wayan Murjana Yasa \\ Fakultas Ekonomi dan Bisnis, Universitas Udayana \\ Email: ${ }^{1}$ murjanayasa@yahoo.co.id
}

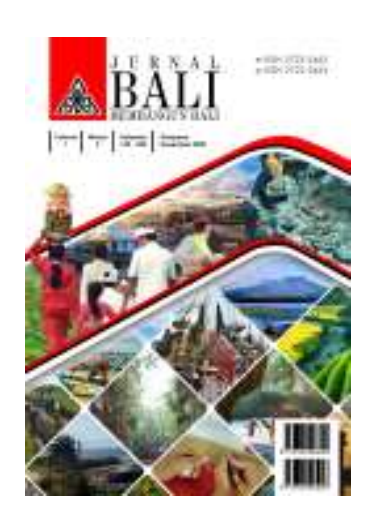

Article History

Received on 15 juli 2020

Revised on 17 Juli 2020

Accepted on 10 Agustus 2020

\begin{abstract}
Purpose: The COVID-19 pandemic has a huge impact on the lives of Balinese citizens. The aim of this study is to find the right steps and frameworks that enable to reduce the spread and death caused by COVID-19 as quickly and as minimally as possible, so that the sustainable impact on the socioeconomic can be reduce.

Research methods: Preventive measures are needed, especially for the Field Facilitator Staff as the front guard, so that the BSPS program channelled adequately. The key to smooth distribution, in addition to the precise mechanism, must also follow the government's recommendations and implement health protocols.

Findings: The results show that the population and employment structure of Bali has high potential for the spread of the COVID-19 pandemic. This is due to the high level of population mobility, both population mobility between regions within the country and population mobility between countries. The second cause is the Balinese population structure consists of many elderly people, thus causing a high potential case fatality rate from a pandemic.

Implications: Based on the results of the study, it is recommend minimize the possibility of the spread of covid-19 through the first and second rapid tests involving as many residents that potential to be covid-19 deployment carrier, both through local transmission and imported cases.
\end{abstract}

Keywords: COVID-19, pandemic, case fatality rate, population mobility, rapid test.

\section{Abstrak}

Tujuan: Pandemi COVID-19 telah berdampak luas terhadap kehidupan masyarakat Bali. Tujuan dari penelitian ini adalah menemukan langkah dan framework yang tepat yang memungkinkan persebaran dan fatalitas dari kasus persebaran COVID-19 dapat ditekan secepat dan seminimal mungkin, sehingga dampak lanjutan terhadap ekonomi sosial dapat ditekan.

Metode Penelitian: Penelitian didasarkan pada data sekunder terpublis yang dikumpulkan dari hasil observasi yang diolah secara deskriptif.

Temuan: Hasil penelitian menunjukkan bahwa dari struktur kependudukan dan ketenagakerjaan Bali memiliki potensi tinggi untuk persebaran pandemi COVID-19 disebabkan karena tingkat mobilitas penduduk yang tinggi, baik antar wilayah di dalam negeri, maupun antar negara, kedua struktur penduduk Bali yang sudah tergolong tua sangat potensial mempercepat potensi tingginya case fatality rate dari pandemi.

Implikasi: Berdasarkan hasil studi tersebut direkomendasikan untuk memperketat kemungkinan penyebaran melalui rapid test pertama dan kedua menyangkut sebanyak-banyaknya penduduk yang berpotensi sebagai carrier penyebaran COVID19 , baik melalui transmisi lokal maupun imported case.

Kata kunci: COVID-19, pandemi, case fatality rate, mobilitas penduduk, rapid test. 


\section{INTRODUCTION}

The COVID-19 pandemic, which was first discovered in Wuhan (China) in December 2019 and has hit more than 200 countries in the world, has been able to destroy the joints of basic life in health, the education economy and others. In Indonesia, the World Bank managing director reported that the impact of the COVID-19 pandemic was more devastating than the 1997/1998 economic crisis and other crises that had occurred. The morbidity rate is accompanied by a high mortality rate. As a world tourist destination, Bali is very concerned about the widespread impact of the COVID-19 pandemic on economic development and job opportunities.

There are links between aspects of health, population and economy, including employment opportunities. Humans and a healthy environment will be able to increase productivity and economic opportunities, as well as promote economic growth. As for the COVID-19 Pandemic, it is not only a matter of how to predict the impact that has occurred, but for Bali, which is affected by this pandemic, the most important thing is how to solve the COVID-19 pandemic as quickly as possible. From the health aspect, there are important indicators that need to be observed, firstly the speed of transmission, secondly the high rate of cure, and thirdly the low mortality rate as a result of COVID-19 infection. The success in suppressing the pandemic allows the economy (especially tourism) to grow and in turn, employment opportunities can reappear.

From a demographic aspect, the transmission of the COVID-19 pandemic is closely related to human movement or population mobility. Population mobility refers to the movement of the population from one area to another within a certain period of time. This movement of population between regions concerns the lowest regional areas to the regions between provinces within a country and between countries. In terms of population development, Bali is closely related to the high number of migrants entering this region. During the last three decades, Bali has experienced the phenomenon of positive net migrant workers (the last 5 years), which means that there are more people who enter than those who leave. Most of them go to the South Bali area, especially Badung and Denpasar City. Theoretically, the higher the mobility of 
people between regions and between countries, the higher the chances of the transmission of COVID-19 being accelerated

When COVID-19 broke out, many countries went into lockdown, including the countries of origin of Bali tourists. When the countries of origin of tourists are improving, and Bali is still struggling with the Pandemic, it is impossible for tourists to come, meaning that Bali tourism will not be able to rise if the COVID-19 Pandemic in Bali is over. So there is a link between the success of completing the COVID-19 Pandemic and the development or recovery from Bali tourism. Furthermore, job opportunities are theoretically a derivative demand, meaning that if the economic sector (especially tourism rises), then job opportunities will also arise.

The question to be answered in this paper is how the right strategy will enable the COVID-19 Pandemic in Bali Province to be ended as quickly as possible in order to restore world confidence that Bali is capable of taking the right and fast steps in overcoming the COVID-19 Pandemic.

\section{RESEARCH METHODS}

This paper is based on a descriptive study that provides descriptions of several single phenomena and then tries to link these phenomena to one another, especially in relation to the COVID-19 pandemic and aspects of population (occupation mobility and employment. The data used are sourced from published data through Official sources, such as the Central Bureau of Statistics, Government Institutions (especially the Provincial Government of Bali), and also from the media The data was collected through non-participant observation, then processed descriptively.

\section{RESULTS AND DISCUSSION}

The discussion in this paper is divided into three parts, the first is related to the development of the COVID-19 Pandemic, especially in the Province of Bali, Second, population mobility is associated with the potential for transmission, the three aging Balinese population structures as a potential transmission, the fourth labor conditions as a result of the spread of COVID-19. In more detail, it is described as follows. 


\section{The Development of the Covid-19 Pandemic in Bali Province and Its} Causes

Since the confirmed case of COVID-19 in Bali on March 10, 2020, its development has continued to increase. As of April 22, 2020, it was confirmed that the number of positive COVID-19 cases in Bali Province reached 152 cases, compared to Indonesia which reached 7,135 cases, then on April 15, 2020 the number of cases increased to 177 compared to Indonesia 8,211. The number who died in the same period each was 4 cases in Bali, while in Indonesia it increased from 616 to 689 deaths. Thus the Case Fatality Rate (CFR) in Bali decreased from 2.63 on 22 April to 2.26 on 25 April 2020. In the same period Indonesia's CFR also decreased from 8.63 to 8.39 (Table 1).

Table 1. Case Fatality Rate (CFR) Development of COVID-19 in Indonesia and Bali Province (16 April-22 April 2020)

[Source: Babe, Data on COVID-19 in Indonesia, 2020]

\begin{tabular}{|c|c|c|}
\hline Wilayah & Per 16 April 2020 & Per 22 April 2020 \\
\hline \multicolumn{3}{|l|}{ Indonesia } \\
\hline 1. Positif & 7.135 & 8.211 \\
\hline 2. Sembuh & 842 & 1.002 \\
\hline 3. Meninggal & 616 & 689 \\
\hline 4. CFR & 8,63 & 8,39 \\
\hline \multicolumn{3}{|l|}{ Bali } \\
\hline 1. Positif & 152 & 177 \\
\hline 2. Sembuh & 47 & 55 \\
\hline 3. Meninggal & 4 & 4 \\
\hline 4. CFR & 2,63 & 2,26 \\
\hline
\end{tabular}

What is worrying about the COVID-19 Pandemic in Bali is that the number of confirmed cases continues to increase. This increase was mainly due to local transmissions. In Figure 1, it can be seen that the development line of confirmed cases is not much different from local transmission, which means that the spread of COVID-19 in Bali is mostly caused by local transmission. Local transmission occurs due to human movement locally, within households or with surrounding communities. It does not rule out that local transmission was initially caused by human movement between countries (international transmission). In the case of Bali where there are many Indonesian Migrant 
Workers (PMI), the potential for spread through international transmission that triggers local transmission is very likely.

The experience of several countries that have relatively succeeded in completing and suppressing the COVID-19 Pandemic and its Case Fatality Rate (CFR), can be seen, for example, Vietnam which managed to control COVID-19 in a relatively fast time with a CFR equal to zero. What they are doing is intensifying the rapid test as much as possible of the population that has the potential to experience transmission as an early detection effort against the spread. Some countries that have been quite successful in reducing the spread and fatality rate of the COVID-19 pandemic include Taiwan, South Korea, Canada, Georgia, Iceland, and Sweden (Liputan6.com, downloaded April 30, 2020). This quick move was very successful in suppressing the development of cases and CFR. The mystery of the low mortality rate is happening in India, what they are doing is how to count the days when the death rate can be further suppressed (Suara.com, Downloaded April 30, 2020).

Population mobility between regions dominates population movements in Bali Province. This population mobility includes movement of internal population between districts / cities in Bali Province, and also between regions between provinces. The mobility of the internal population in the regency / municipality tends towards the South Bali areas. The results of the 2015 Inter-Census Population Survey (BPS, 2016) show that for 5 years the number of risen migrants in Bali Province reached more than 37000 people or an average of around 28000 people each year. They mostly come from several nearby provinces in Java and Nusa Tenggara, such as East Java, Central Java, DKI Jakarta, West Java, West Nusa Tenggara, and East Nusa Tenggara. 


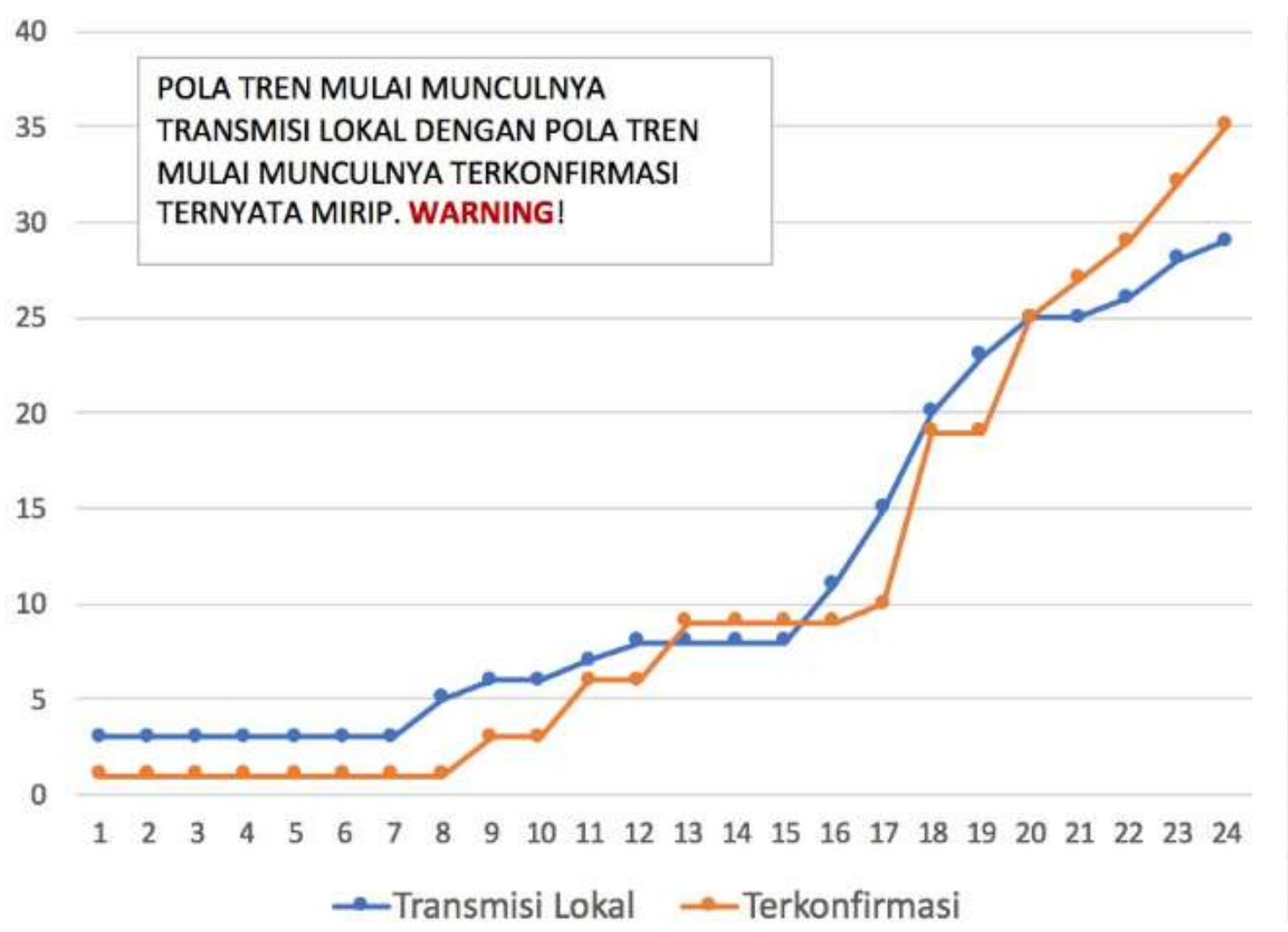

Figure 1. Development of Confirmed Cases of COVID-19 and Local Transmission in Bali Province, Data as of 22 April 2020

[Source: Bali Provincial Government's Task Force for the Acceleration of Handling COVID-19, 2020].

The high inward mobility of risen migrants from various regions is a cause for concern. We already know that several areas of origin of migrants who enter Bali Province, especially those from Java, are the epicenter of the COVID-19 Pandemic, so if the mobility of the population between these regions cannot be controlled, the potential for the spread of the COVID-1 Pandemic will be more widespread and in the long run relatively longer time.

Cultural-based traditional population mobility that is carried out from generation to generation in Indonesia, which is generally carried out on H-14-D7 of Idul Fitri (or $\mathrm{H}-14-\mathrm{H}-7$ Idul Fitri) and the return flow of $\mathrm{H}=7-\mathrm{H}+14$ of Idul Fitri (or arus balik $\mathrm{H}=7-\mathrm{H}+14$ Idul Fitri), especially when the COVID-19 outbreak has spread, also has the potential to expand and extend the spread pandemic through human movement. The transportation facilities they use, whether buses, private vehicles, motorbikes, also have the potential to increase transmission. On the trip, the various facilities they use such as rest areas, 
public bathrooms, and others are also potential sources of transmission, not to mention meeting relatives who are not yet known whether they are infected or not. So the perpetrators of mobility as well as family and adulthood in the area of origin and destination have the same potential as a source of infection.

Going home by some migrants also has the potential to accelerate transmission. Many of those who used to work in the city did their homecoming activities, but as a result of COVID-19 they decided to return to their hometowns to try to find new fortunes, including those who only visited for family purposes.

International transmissions can be caused by visiting tourists or through international mobility of Indonesian Migrant Workers (PMI). As per April 16, 2020, as reported by the Bali Post (Bali Post, April 22, 2020), around 22,000 PMIs from Bali have returned. They come from various regencies / cities in Bali Province. Of those who have returned, rapid tests have been carried out regarding the possibility of contracting COVID-19, and further steps have been taken. Those who are negative are welcome to self-quarantine. The issues that are of concern here are those who take self-quarantine, but they lack discipline. Those who tested negative in the initial rapid test, there is still a possibility that the next week's test will be positive. This condition will have a further impact on the possibility of local transmission. So international transmission which has a further impact on the distribution is triggered by local transmission.

The importance of maintaining vigilance against the pattern of the spread of the COVID-19 Pandemic in Bali Province is also due to the aging structure of the Balinese population. As is well known, Bali is one of the five provinces in Indonesia whose population includes the elderly. A province is said to have an old population age structure, if 10 percent or more of the population is over 60 years old. Older people are very susceptible to various degenerative diseases which can be fatal if they are also infected by COVID-19.

\section{COVID-19 and Termination of Employment}

Economically Active Population are those aged 15 years and over and are able to produce goods and or services. In Indonesia, they are residents aged 15 years and over. These economically active people are differentiated 
between those who are working and looking for work. For Bali Province, based on the results of the National Socio-Economic Survey (SUSENAS) in August 2019, the number of economically active people (labor force) reached 2,466,230 people, of whom 2,428,679 people (98.48 percent) worked, and the remaining 37,551 people ( 1.52 percent) are looking for work (BPS, 2020). What is concerned about the development of COVID-19 related to employment is the large potential for the emergence of new job seekers as a result of layoffs (PHK) and also from workers who have been temporarily laid off.

Based on data compiled by the Bali Provincial Manpower Office, (Bali Post, 22 April 2020: 1), out of 748 companies that reported as of April 16, 2020, there were 52,387 employees who were sent home, 84 companies reported 1,204 employees who were laid off (Table 2). This number does not include employees who have laid off themselves and who have laid off themselves due to economic downturns. Of those who were sent home, some still received a salary of between 25 and 75 percent, and many were sent home without a salary. Likewise for those who were laid off, many were without severance pay. This condition has logical consequences, firstly those who are laid off and affected by layoffs have an impact on increasing unemployment, secondly those who have been unemployed are added with new unemployment as a result of employees being laid off and laid off, which brings logical consequences to efforts to provide social safety networks for them.

Table 2. Number of cases of employees being dismissed and terminated at Province of Bali, As of April 15, 2020 [Source: Bali Post, 22 April 2020: 1]

\begin{tabular}{lrr}
\hline Kabupaten/Kota & Dirumahkan (orang) & PHK (Orang) \\
Jembrana & 333 & 8 \\
\hline Tabanan & 480 & 1 \\
Badung & 28.609 & 631 \\
Gianyar & 9.813 & 177 \\
Klungkung & 682 & 6 \\
Bangli & 381 & 0 \\
Karangasem & 2.085 & 13 \\
Buleleng & 2.140 & 134 \\
Denpasar & 8.074 & 338 \\
Bali & $\mathbf{5 2 . 3 8 7}$ & $\mathbf{1 . 2 0 4}$ \\
\hline
\end{tabular}


In the era of the COVID-19 pandemic, new creative job opportunities have also emerged. These job opportunities, such as meeting the needs for masks prepared by MSMEs, the emergence of home industry opportunities, such as culinary, as well as various job opportunities opened up in rural areas.

\section{Strategy for Accelerating the Response to COVID-19}

The root cause of the emergence of various social and economic problems from the COVID-19 phenomenon is the COVID-19 Pandemic, therefore the focus of solving the problem of the impact of COVID-19 is to immediately suppress its spread, increase the rate of cure, and suppress fatalities. Rapid tests 1 and 2 for the majority of the population who are potentially infected are very important as an initial prevention effort.

Taking into account the condition of the Balinese population which has high human mobility, as well as the aging population structure, various policies and strategies that have been taken by the government, related to physcal distancing, and social distancing must be made effective. Limiting the flow of homecoming, returning and returning home can be an important solution in reducing the possibility of distribution. The results of a study by the Institute for Development of Economics and Finance (INDEF) regarding the handling of the COVID-19 outbreak and its economic impact recommend the following points (Fadjarudin, 24 March 2020): Regional quarantine to prevent the spread of COVID-19, Refocusing the Budget on handling the COVID-19 Pandemic 19, save people and sacrifice the economy in the short term, and for industry, the only stimulus provided is to prevent a wave of layoffs from occurring.

What can be discussed from INDEF's findings is that, when the COVID19 Pandemic broke out, the main issue that needed to be addressed was the issue of the spread of COVID-19, then the economic problems that were the impact of the pandemic. In the economic concept of human resources, employment is a derivative demand, meaning that employment opportunities occur when there is a demand for them, namely from the emergence of investment opportunities as a result of economic revival. When recovery occurs, after COVID-19, job opportunities will start to emerge again 


\section{CONCLUSION}

Based on the results of descriptive analysis, the following conclusions can be made. In terms of population, the population of Bali has the potential to support the acceleration of the COVID-19 pandemic through a high pattern of population mobility, both between regions in Bali Province, between regions in Indonesia, and between countries. The COVID-19 pandemic in Bali Province was mainly triggered by local transmissions, as well as imported cases.

The key factor for Bali's success in carrying out economic recovery is the success in suppressing the spread of COVID-19, increasing the cure rate and reducing the number of fatal cases. This success will smooth out the recovery in the economy and employment sector.

\section{REFERENCES}

Badan Pusat Statistik Provinsi Bali. 2020. Berita Resmi Statistik: Keadaan Ketenagakerjaan Provinsi Bali. Denpasar: BPS.

Badan Pusat Statistik Provinsi Bali. 2016. Statistik Migrasi Bali Hasil Survei Penduduk Antar Sensus 2015. BPS. URL: https://www.bps.go.id. Downloaded: 30 April 2020.

Fadjarudin, Muchlis. 24 Maret 2020. Hasil Kajian INDEF Soal Penanganan Wabah COVID-19 dan Dampak Ekonominya. Jakarta: Economi dan Bisnis. URL: https://www.suarasurabaya.net. Downloaded: 30 April 2020. Juniartini, Ni Luh Putu; I Wayan Juniartha; I Nyoman Anom Fajaraditya Setiawan. 2020. The Distribution Process of the Housing Stimulant Grants Program (BSPS) during COVID-19 Pandemic Situation in Muncan Village, Karangasem Regency. Retrieved from: http://ejournal.baliprov.go.id/index.php/jbmb/article/view/110.

Kompas.com. Nol Kasus Kematian, Begini Cara Vietnam Sukses Tangani Virus Corona. URL:https://www.msn.com. Downloaded: 30 April 2020 Liputan6.Com. Kisah Sukses 7 Negara Menekan Penyebaran Virus Corona COVID-19. URL: https://m.liputan6.com. Downloaded: 30 April 2020. 
Permana, I Putu Hendika. 2020. Analisis Media Online sebagai Sumber Informasi Wisatawan Australia dalam Mendapatkan Informasi Virus Corona di Bali. Jurnal Bali Membangun Bali, Volume 1, Nomor 2, Agustus 2020. Retrieved from:

http://ejournal.baliprov.go.id/index.php/jbmb/article/view/111.

Suara.com. Misteri di Balik Tingkat Kematian Yang Rendah Akibat COVID_19 di India, Ada Apa?. URL: http://babe.topbuzz.com. Downloaded: 30 April 2020.

Tim Editor. 2020. "Covid-19 Belum Berlalu, JBMB Harus Terus Berkembang", Jurnal Bali Membangun Bali, Volume 1, Nomor 2, Agustus 2020. Retrieved from:

http://ejournal.baliprov.go.id/index.php/jbmb. 
154 | I Gusti Wayan Murjana Yasa 